\title{
Perancangan dan Implementasi Modul Praktikum \\ Pengenalan Tata Letak dan Port I/O pada Mother board berbasis Teknologi Augmented Reality
}

\author{
Gita Indah Hapsari ${ }^{1}$, Giva Andriana Mutiara ${ }^{2}$, Rini Handayani ${ }^{3}$ \\ ${ }^{1,2,3}$ Program Studi Teknik Komputer Fakultas Ilmu Terapan Universitas Telkom \\ ${ }^{1,2,3}$ Jalan Telekomunikasi, Ters. Buah Batu, Bandung, 40257, Indonesia \\ ${ }^{1}$ gitaindahhapsari@tass.telkomuniversity.ac.id, ${ }^{2}$ giva.andriana@ tass.telkomuniversity.ac.id \\ ${ }^{3}$ rini.handayani@tass.telkomuniversity.ac.id
}

\begin{abstract}
Abstrak - Kemajuan teknologi berbasis komputer berkembang dengan sangat pesat. Seiring dengan perkembangan jaman, kemajuan tersebut memberikan pengaruh terhadap perubahan cara penyampaian pengajaran yang mengarah pada penggunaan jenis media penyampaian. Praktikum merupakan salah satu bentuk pengajaran yang memberikan pengalaman belajar secara nyata terhadap kondisi sebenarnya di lapangan mengenai penggunaan dan implementasi alat praktek yang berhubungan dengan berbagai materi yang dipelajari oleh mahasiswa dan memiliki tujuan untuk memberikan keterampilan dan pengenalan terhadap mahasiswa/peserta didik. Penelitian ini melakukan implementasi teknologi augmented reality terhadap salah satu modul praktikum yaitu pengenalan tata letak hardware dan Port I/O pada motherboard dan bertujuan sebagai alat bantu penyampaian pengajaran praktikum. Pengimplementasian teknologi augmented reality melibatkan aksi oleh user terhadap media penangkapan gambar motherboard menggunakan web camera dan tampilan pemetaan tata letak hardware dan port i/o pada motherboard. Penelitian telah diimplementasikan dan diujicoba terhadap 3 kelas dengan 97 responder. Adapun hasil dari penelitiannya adalah $83 \%$ responder menyukai aplikasi, 77\% memahami materi, 84,5\% menginginkan aplikasi ini menjadi alat bantu ajar, 65,98\% meminta materi untuk dilengkapi dan diperbanyak, 77,3\% dapat belajar mandiri menggunakan aplikasi ini, tanpa bantuan dari dosen ataupun asisten.
\end{abstract}

Kata kunci - praktikum, augmented reality

Abstract - The Enhancement of computer-based technology develops very fast. As time goes by, these advances make significant influence on the changes of teaching methods. Practicum is a form of teaching that provides a real learning experience for actual field conditions regarding the use and the implementation of practical tools associated with different materials studied by students. The goal of practicum is to give an introduction, also provide and improve the skills for the students / learners. This research is doing the implementation augmented reality technology on the one of the lab module. The module is the introduction of the layout of hardware and I / $\mathrm{O}$ ports on the motherboard and intended as a tool for the delivery of teaching practicum. The implementation of Augmented Reality Technology involves user's action whereas user will capture the image of motherboard using web camera and the system will display the mapping layout hardware and port I/O in the motherboard. This research has been implemented and tested on 97 responders from three parallel class. The result are 83\% responder like the using of this application, $77 \%$ can understand the material which is giving in the application, $84.5 \%$ responder wants this application to be implemented on the module, $65.98 \%$ responder told to complete this application with much more material, $77.3 \%$ responder can do the practicum by her/himself without any instructor or lecturer.

Keywords-component; practicum, augmented reality

\section{PENDAHULUAN}

Pada awalnya pembelajaran dilakukan secara konvensional, dimana dosen dan mahasiswa secara terjadwal bertemu dalam suatu kelas. Biasanya dosen melakukan pengajaran secara konvensional dan membimbing mahasiswa dengan berbagai metoda pengajaran. Salah satu metode pemberian materi pada proses belajar mengajar adalah praktikum. Praktikum merupakan suatu bentuk pengajaran untuk memberikan pembelajaran mengenai keterampilan menggunakan suatu alat dengan tujuan implementasi suatu sistem atau konsep. Metode pembelajaran praktikum selalu disertai dengan pendampingan media kertas berupa modul, kit praktikum, dengan pendampingan dosen atau asisten yang ditugaskan.

Seiring dengan perkembangan jaman, media pendampingan pada metode pembelajaran praktikum dapat dikombinasikan dengan kemajuan teknologi. 
Salah satu teknologi yang dapat dikombinasikan dengan penyampaian metoda pembelajaran adalah teknologi Augmented Reality (AR). Teknologi Augmented Reality (AR) ini merupakan teknologi yang menggabungkan benda maya 2 dimensi dan atau 3 dimensi ke dalam sebuah lingkungan nyata 3 dimensi, kemudian memproyeksikannya dalam waktu nyata. Penggabungan benda nyata dan maya dimungkinkan dengan teknologi tampilan yang sesuai. Penggabungan tersebut akan menghasilkan Mixed reality (MR). Pada tahun 1994, Millgram dan Kishino merumuskan penggabungan dan peleburan dunia nyata dan maya ke dalam sebuah continuum virtuality yang dapat dilihat pada Gambar 1 di bawah ini. Teknologi ini meningkatkan persepsi dan interaksi para pengguna dengan dunia nyata terutama dengan AR [1].

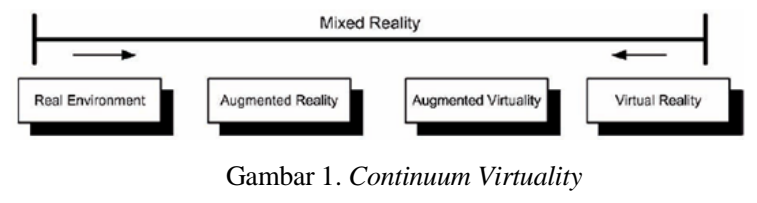

Teknologi AR dipilih karena mempunyai keunggulan sebagai berikut.

1. Dapat memperluas persepsi user mengenai satu objek dan memberikan user experience terhadap objek 3D yang ditampilkan

2. interaksi yang tidak dapat dilakukan di dunia nyata

3. Memungkinkan penggunaan perangkat yang beragam sesuai dengan kebutuhan.

Perkembangan teknologi dapat mempermudah dalam mempelajari sesuatu melalui berbagai macam media, seperti media cetak, televisi, internet, gambar, dan lain sebagainya. Hal tersebut dapat diarahkan pada implementasi suatu proses belajar mengajar, sehingga suatu proses pembelajaran menjadi lebih bermakna berdasarkan kerucut pengalaman Edgar Dale seperti pada Gambar 2 di bawah ini.

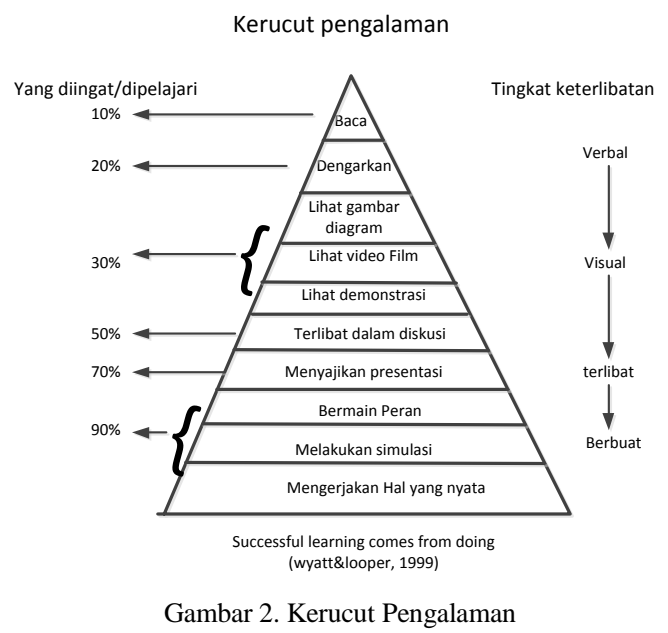

Teknologi Augmented Reality dibuat dengan menggunakan software D'Fusion ${ }^{\circledR}$ AR dengan bahasa pemrograman Lua Scripting (frame) yang merupakan perangkat lunak yang dibuat oleh Total Immersion untuk merancang dan membuat aplikasi AR. Selain itu, software yang digunakan untuk pemunculan teks adalah 3D Max. Pembuatan aplikasi AR merupakan kombinasi dari teknologi :

1. Pengenalan citra atau object

2. Pelacakan target yang bergerak

3. Render object $3 D$ secara real time.

Berdasarkan hal-hal tersebut di atas, maka dibuatlah suatu alat bantu media belajar praktikum mandiri mengenai implementasi teknologi Augmented Reality dengan media penangkapan gambar menggunakan web camera, dan suara mengenai penjelasan komponen hardware yang muncul pada saat penangkapan gambar terjadi.

\section{METODOLOGI}

Adapun metodologi yang akan dipakai untuk membuat sistem ini adalah metode prototype. Gambar 3 berikut ini menampilkan urutan metoda prototype menurut buku Pressman Roger S [5] .

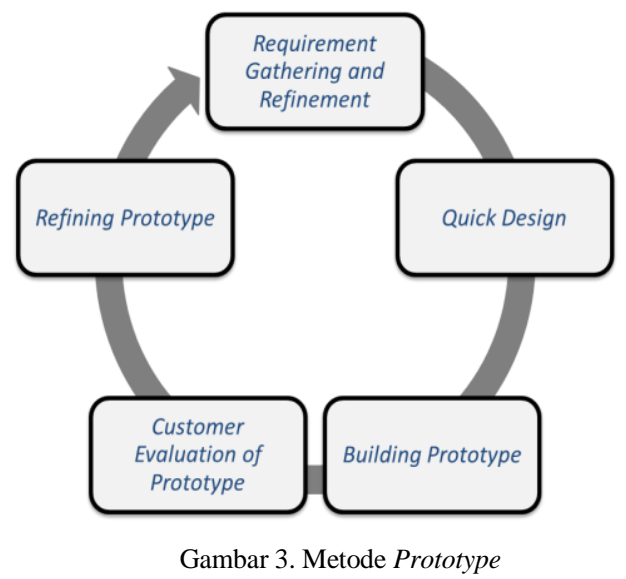

Tahapan metode prototype adalah sebagai berikut.

1. Pengumpulan kebutuhan (requirement gathering and refinement) merupakan tahap identifikasi kebutuhan bersama-sama kemudian mendefinisikan format seluruh perangkat lunak dan semua kebutuhan sistem yang akan dibuat.

2. Pembuatan desain global (quick design) untuk membentuk perangkat lunak yang dibutuhkan.

3. Membangun prototype (Building Prototype) meliputi pembuatan perangkat lunak sampai pengujian dan penyempurnaan.

4. Evaluasi dari pengguna (customer evaluation of prototype) merupakan tahap pengumpulan data dari user berupa kuisioner terhadap aplikasi yang dibuat.

5. Memperbaiki prototype (refining prototype) 
Tahap ini tidak dilakukan pada penelitian ini dan akan dilakukan pada periode pembelajaran berikutnya.

\section{A. Pengumpulan Kebutuhan}

Pada tahap pengumpulan kebutuhan, dilakukan tahap identifikasi kebutuhan bersama-sama yang mendefinisikan format seluruh perangkat lunak dan semua kebutuhan sistem yang akan dibuat. Tahap ini menghasilkan mengenai perangkat lunak apa yang akan digunakan untuk membuat aplikasi, bahasa pemrograman, dan penyamaan visi yang digambarkan pada perangkat lunak berdasarkan modul praktikum yang telah ada dan akan dimodifikasi. Adapun spesifikasi kebutuhan sistem adalah sebagai berikut.

1. Perangkat lunak D'Fusion ${ }^{\circledR}$ AR studio (free Version) dan D'Fusion Exporter dari D'Fusion ${ }^{\circledR} A R$ untuk mengeksport animasi 3D ke $D^{\prime}$ Fusion ${ }^{\circledR} A R^{[9][10]}$.

2. Perangkat lunak yang digunakan dalam proses implementasi animasi dan $3 D$ Obyek adalah $3 D$ Studio Max $2011^{[9][10]}$.

3. Modul Praktikum pengenalan komponen sistem komputer

4. Perangkat keras visualisasi, menggunakan webcam dengan resolusi citra maksimum 2560x2084 dan kapasitas citra sebesar 5 MP.

5. Perangkat keras mother board dan port i/o.

6. Prosesor Dual Core atau setara, RAM minimal $1 \mathrm{~GB}$, ruang sisa harddisk minimal 10 GB dan 1 GB untuk perangkat lunak, kartu VGA dengan memori $256 \mathrm{~B}$ yang mendukung directX dan OpenGL, serta perangkat audio berupa speaker ${ }^{[3]}$.

\section{B. Pembuatan Desain Global}

Setelah proses identifikasi sistem dilakukan maka, selanjutnya dilakukan perancangan mock up berdasarkan modul praktikum yang akan diimplementasikan kepada perangkat lunak yang akan dibuat. Seperti pada gambar 4 berikut ini. Perancangan mock up meliputi perancangan tampilan, narasi suara, dan gambar yang akan digunakan pada aplikasi.

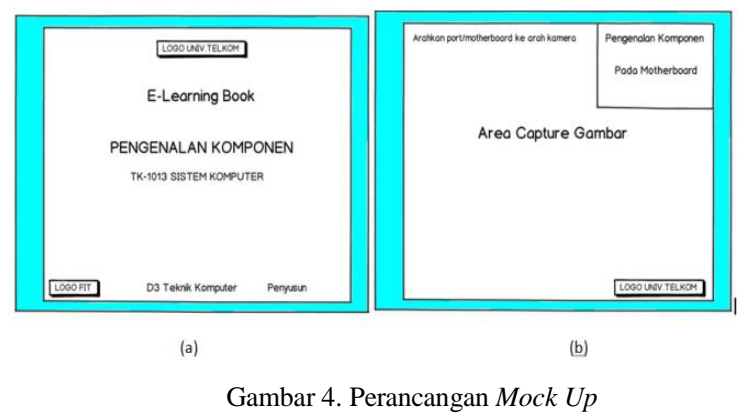

\section{Membangun prototype (Building Prototype)}

Tahap selanjutnya merupakan tahap pembangunan perangkat lunak atau aplikasi berdasarkan perancangan mock up yang rekam suara yang telah dilakukan pada tahap sebelumnya dengan bahasa pemrograman LUA scripting pada perangkat lunak D'Fusion ${ }^{\circledR}$ AR studio (free Version) dan $3 D$ studio Max, dengan langkah seperti pada gambar 5 berikut [11].

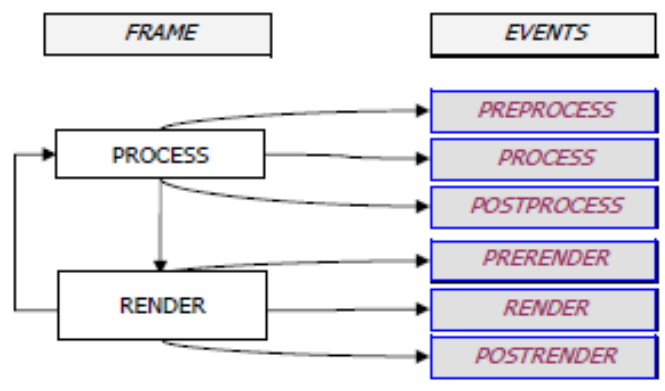

Gambar 5. Langkah eksekusi D'Fusion ${ }^{\circledR} A R$

Pembuatan aplikasi AR merupakan kombinasi dari 3 teknologi berikut.

1. Pengenalan citra atau obyek

2. Pelacakan (trackint) target yang bergerak

3. Render obyek 3D secara real time.

Pada mesin D'Fusion ${ }^{\circledR} A R$, seluruh pemrosesan frame adalah sinkron ${ }^{[7]}$. Sedangkan beberapa proses harus dibuat menjadi thread (seperti manajemen suara, video buffering, dan pemrosesan CV). Semua panggilan yang dibuat pada main loop adalah sinkron sehingga sinkronisasi thread harus dilakukan selama pemanggilan $^{[8]}$.

Setelah selesai melakukan pemrograman, maka program aplikasi kemudian dirender dan diimplementasikan pada laptop/desktop dan diujicobakan pada 3 kelas.

\section{Evaluasi Pengguna (customer evaluation of prototype)}

Tahap evaluasi pengguna dilakukan dengan menguji coba aplikasi terhadap 97 responder yang berasal dari 3 kelas paralel. Aplikasi diujicoba ke dalam perangkat desktop dan laptop di laboratorium. Kemudian user diberikan kuisioner berupa beberapa buah pertanyaan yang berkaitan dengan hasil uji coba sistem.

\section{HASIL PENELITIAN}

Uji coba dilakukan dengan menggunakan desktop dan laptop dengan spesifikasi minimum adalah sebagai berikut.

1. Perangkat visualisasi HMD atau Web Camera dengan resolusi $640 \times 480$, Ujicoba dilakukan dengan menggunakan webcam beresolusi citra maksimum 2560x2084 dengan kapasitas citra sebesar 5 MP.

2. Spesifikasi minimum Perangkat yang digunakan adalah : Prosesor Dual Core atau setara, RAM minimal $1 \mathrm{~GB}$, ruang sisa harddisk minimal 10 GB dan 1 GB untuk perangkat lunak, kartu VGA 
dengan memori $256 \mathrm{~B}$ yang mendukung directX dan OpenGL, serta perangkat audio berupa speaker.

Adapun tahap ujicoba aplikasi adalah sebagai berikut.

1. Aplikasi diinstall

2. Web camera diaktifkan

3. User melakukan praktikum dengan menangkap objek menggunakan web camera serta membaca modul dan melakukan apa yang terdapat pada modul.

Gambar 6 berikut ini adalah gambar use case global dari aplikasi yang merupakan interaksi user terhadap aplikasi perangkat lunak yang telah dibuat.

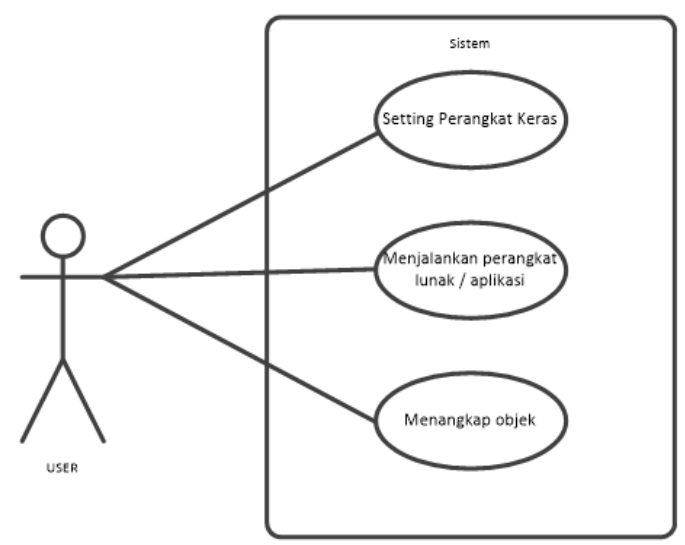

(a). Use case global aplikasi

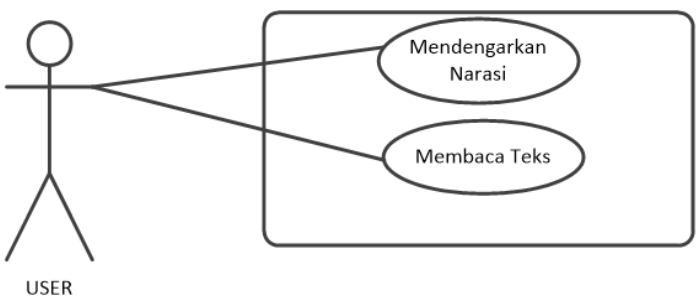

(b). Use case aplikasi praktikum

Gambar 6. Use Case Aplikasi

Hasil Prototipe aplikasi dapat dilihat pada gambar 7, dengan deskripsi sebagai berikut.

1. Pada saat user mengaktifkan aplikasi, tampilan pada Gambar (a) akan muncul dan terdapat narasi suara mengenai informasi yang harus dilakukan oleh user dalam menjalankan aplikasi.

2. Apabila narasi suara telah selesai, maka tampilan akan masuk pada tampilan capture area seperti pada Gambar (b). Web camera akan aktif.

3. User melakukan capture gambar motherboard menggunakan modul seperti tampilan pada Gambar (c) dan muncul narasi suara mengenai komponen-komponen yang tertangkap.

4. Apabila user melakukan capture gambar port i/o menggunakan modul, maka akan muncul tampilan seperti pada Gambar (d) diiringi narasi suara menjelaskan komponen-komponen yang tertangkap pada gambar.

5. Selain dilakukan penangkapan gambar melalui image yang terdapat pada modul, user juga dapat melakukan penangkapan gambar melalui perangkat hardware yang sebenarnya dan hasil tangkap gambar dapat dilihat pada Gambar (e) dan (f) disertai narasi suara yang sama dengan penangkapan gambar pada kondisi (c) dan (d).

6. Berdasarkan tahap uji coba sistem, seluruh fungsi yang dirancang dapat berjalan dengan lancar. Sistem siap diujicoba pada responden. Pembahasan hasil ujicoba pada responden dilakukan pada bab pembahasan.
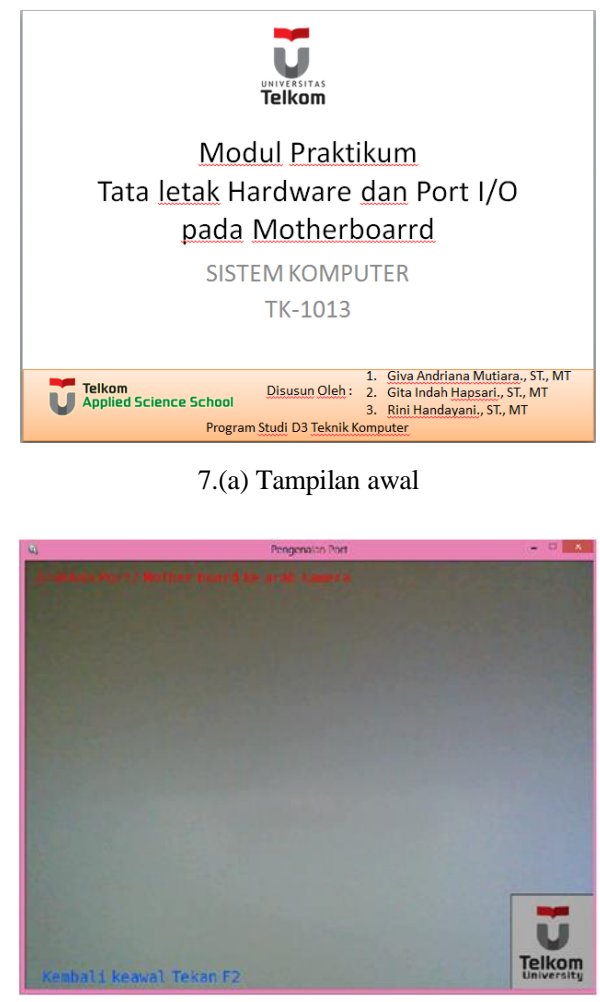

7.(b). Tampilan capture area

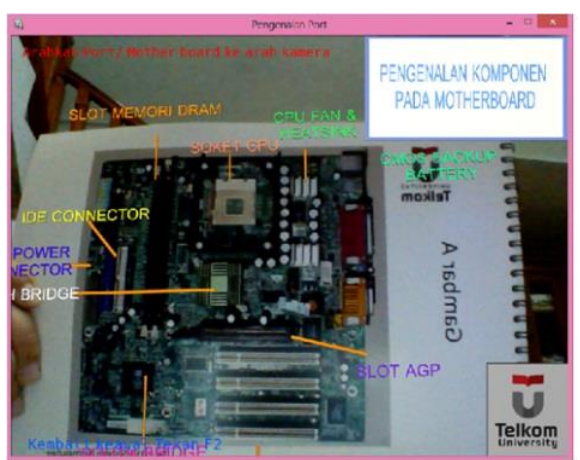

7.(c). Tampilan capture motherboard menggunakan modul 


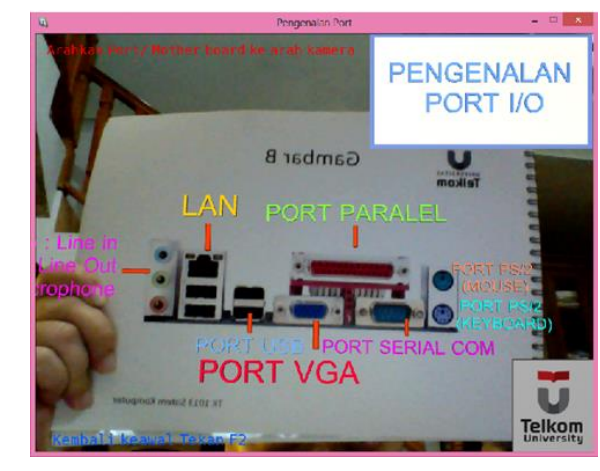

7.(d). Tampilan capture pengenalan port menggunakan modul

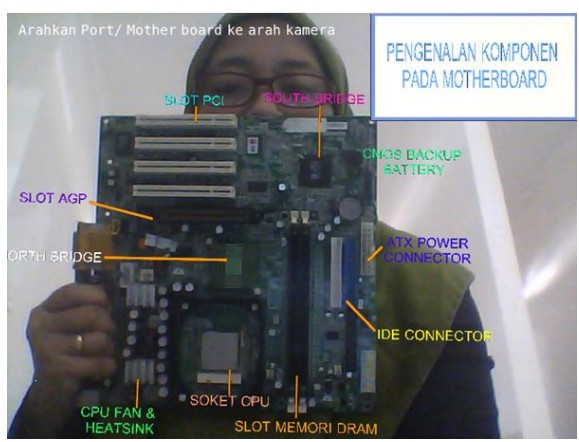

7.(e). Tampilan tangkap gambar perangkat keras motherboard

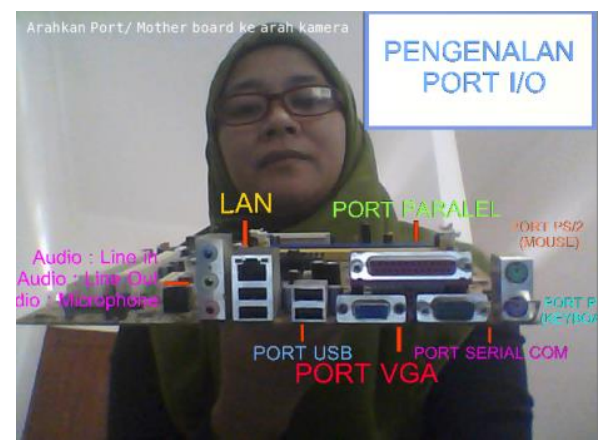

7.(f). Tampilan tangkap gambar menggunakan hardware port $1 / O$

Gambar 7. Deskripsi Jalannya Aplikasi

\section{PEMBAHASAN}

Uji coba aplikasi dilakukan oleh 97 responden yang berasal dari 3 kelas parallel mahasiswa teknik komputer di semester ganjil 2014/2015 dan setiap responden diharuskan untuk mengisi kuesioner yang telah disediakan. Setiap pertanyaan pada kuisioner diberi bobot seperti yang tertera pada Tabel 1 . Sedangkan hasil kuisioner dapat digambarkan pada Tabel 2. Pengambilan waktu kuisioner dilakukan pada saat masing-masing kelas melakukan praktikum.

Tabel 2. Hasil Kuisioner

\begin{tabular}{|c|c|c|c|c|c|c|c|}
\hline \multirow{2}{*}{ No } & \multirow{2}{*}{ Pertanyaan } & \multicolumn{5}{|c|}{ Jumlah Responder } & \multirow{2}{*}{$\begin{array}{c}\text { Jumlah } \\
\text { Total }\end{array}$} \\
\hline & & $\mathbf{1}$ & 2 & 3 & 4 & 5 & \\
\hline 1 & Tanggapan anda mengenai aplikasi ini & 0 & 1 & 15 & 37 & 44 & 97 \\
\hline 2 & $\begin{array}{l}\text { Aplikasi ini membuat Anda lebih paham tentang } \\
\text { materi yang disampaikan }\end{array}$ & 2 & 1 & 19 & 44 & 31 & 97 \\
\hline 3 & Aplikasi ini dapat dijadikan alat bantu pengajaran & 0 & 1 & 14 & 47 & 35 & 97 \\
\hline 4 & $\begin{array}{l}\text { Kecukupan terhadap kelengkapan media dan } \\
\text { materi yang disampaikan pada aplikasi ini }\end{array}$ & 0 & 2 & 31 & 41 & 23 & 97 \\
\hline 5 & $\begin{array}{l}\text { Aplikasi ini membuat anda menjadi lebih mandiri } \\
\text { dalam berpraktikum }\end{array}$ & 0 & 1 & 21 & 50 & 25 & 97 \\
\hline
\end{tabular}

Rekapitulasi grafik hasil kuisioner berdasarkan tabel di atas dapat dilihat pada gambar 8 berikut ini.

\begin{tabular}{lc}
\multicolumn{2}{c}{ Tabel 1. Bobot Kuisioner } \\
\hline \multicolumn{1}{c}{ Jenis Pilihan } & Bobot \\
\hline Sangat Baik & 5 \\
Baik & 4 \\
Cukup & 3 \\
Buruk & 2 \\
Sangat Buruk & 1 \\
\hline
\end{tabular}




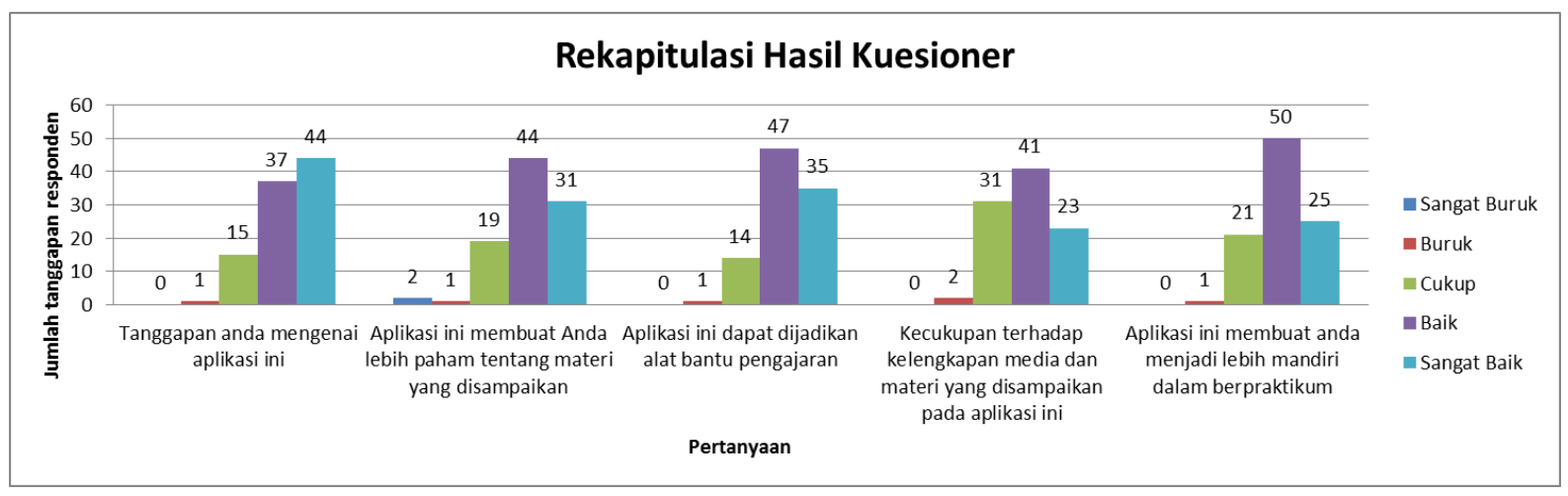

Gambar 8. Rekap Kuisioner Responden

Berdasarkan dari analisa hasil kuisioner dapat dilihat pada grafik bahwa, $83 \%$ responden menyukai aplikasi yang digunakan untuk menunjang kegiatan praktikum mandiri, $77 \%$ responden memahami materi yang disampaikan melalui aplikasi, 84,5\% responden menginginkan aplikasi ini untuk dijadikan alat bantu ajar, $65,98 \%$ responden meminta materi untuk dilengkapi dan diperbanyak pada materi-materi praktikum lainnya dan meminta untuk memperbanyak rambu-rambu pemberitahuan pendalaman materi yang harus dikembangkan atau dicari sendiri, $77,3 \%$ responden dapat belajar mandiri menggunakan aplikasi ini, tanpa bantuan dari dosen ataupun asisten.

Berdasarkan analisa di atas, maka masukanmasukan yang berasal dari hasil kuisioner seperti kelengkapan materi, memperbanyak penerapan sistem serupa pada modul lain, akan dijadikan dasar untuk memperbaiki sistem sehingga menghasilkan perangkat lunak yang jauh lebih baik lagi untuk diimplementasi di semester yang akan datang.

\section{PENUTUP}

\section{A. Kesimpulan}

1. Aplikasi berhasil diimplementasikan pada desktop dan laptop.

2. Secara garis besar maka dapat disimpulkan bahwa mahasiswa yang melakukan ujicoba terhadap sistem pengenalan komputer ini menyukai dan memahami materi, dan dapat melakukan belajar mandiri, sehingga menginginkan aplikasi ini dijadikan alat bantu ajar dan meminta untuk memperbanyak implementasi sistem serupa pada modulmodul lainnya.

B. Saran

1. Aplikasi diimplementasikan pada aplikasi elearning di web site i-gracias milik Universitas Telkom

2. Melanjutkan penelitian untuk ke arah pemunculan perancangan 3 Dimensi yang lebih interaktif.
3. Menggunakan tools perangkat lunak yang bukan free version (karena terbatas fiturnya) dan masih ada watermarking di dalam penampilan aplikasi yang dibuat.

\section{DAFTAR PUSTAKA}

[1] Azuma, R.T., et. al.,. Recent Advances in Augmented Reality. IEEE Computer Graphics Application.(2001)

[2] De Landgraaf, W.A.. Interaction beetween users and augmentad reality system: Human-Computer Interaction of the future, an essay for HCI, Vrije Universiteit Amsterdam. (2003-2004)

[3] Gita, I., Aciek,I.. Perancangan dan Implementasi Media Pendidikan Kesehatan Gigi untuk Anak-anak Berbasis Teknologi Augmented Reality. Publisher: Institut Teknologi Bandung. (2012)

[4] Giva, A.M, Gita, IH, Rini, H. Design and Implementation Learning Media of a Computer Hardware Introduction as a Teaching Tool Based-on Augmented Reality Technology. Conntemporary Engineering Sciences, Vol.7, 2014, no.13 611-616 http://dx.doi.org/10.12988/ces.2014.4667

[5] Pressman, Roger S, Software Engineering, A Practitioner's Approach. $7^{\text {th }}$ edition, The McGrawHill Companies, Inc 1221 Avenue of the Americas, NewYork, NY 10020

[6] NN, 2005, 7 Things You Should Know About Augmented Reality, Educase Learning Initiative.

[7] , D'Fusion® 3.2 Technical Description, Total Immersion, http://community.timmersion.com/, diakses 14 Juli 2012, 04:35 WIB.

[8] _ D'Fusion ${ }^{\circledR}$ Augmented Reality Reference Manual, Total Immersion, http://community.t-immersion.com/, diakses 14 Juli 2012, 04:35 WIB.

[9] _ D'Fusion ${ }^{\circledR}$ Exporter for $3 D s$ MAX : Modelling and Constraint, Total Immersion, http://community.t-immersion.com/, diakses 14 Juli 2012, 04:35 WIB.

[10] , D'Fusion ${ }^{\circledR}$ Exporter for 3Ds MAX : User Manual, Total Immersion, 2011, http://community.t-immersion.com/, diakses 14 Juli 2012, 04:35 WIB.

[11] _ D'Fusion ${ }^{\circledR}$ Studio user Guide, Total Immersion, http://community.timmersion.com/, diakses 14 Juli 2012, 04:35 WIB. 